\title{
Which Came First: Literacy or Social Studies? How Primary Sources Can Bridge the Divide
}

Excelsior: Leadership in

Teaching and Learning 2021, Vol. 13(3), 182-196

(C) The Author 2021

CC-BY 4.0 International Reprints and permissions: surface.syr.edu/excelsior https://doi.org/10.14305/in.19 440413.2021.13.3.01

nyacte.org

(ib) Elise Langan ${ }^{1}$ and (i) Salika A. Lawrence ${ }^{2}$

\begin{abstract}
Due to the implementation of No Child Left Behind and the Common Core State Standards, disciplinary literacy has become a vital component of social studies instruction in middle and secondary classrooms. This paper determines the degree to which nine middle and high school social studies teachers were successful in designing integrated learning experiences for their students after attending professional development. Data from semi-structured interviews, teachers' instructional units, workshop surveys and field notes were collected and analyzed for the qualitative study. The study considers how teachers' instructional units incorporated primary sources to support students' foundational literacy skills, scaffolded disciplinary understanding, utilized historical analysis, and highlighted community issues that connected their lived experiences to broader social concerns.
\end{abstract}

\section{Keywords}

student-centered inquiry, disciplinary literacy, social studies, Common Core State Standards, primary sources, C3

More than a decade ago, Massey and Heafner (2004) noted that the discipline of social studies requires teachers to recognize that they are teaching reading and writing as well as content. The Common Core State Standards (CCSS) advanced these expectations by emphasizing disciplinary literacy and making literacy instruction every teacher's responsibility (National Governors Association Center for Best

\footnotetext{
${ }^{1}$ Bronx Community College (CUNY)

2 The College of New Jersey

Corresponding Author: Elise Langan, Bronx Community College, 2155 University Avenue, Colston Hall 434, Bronx, NY 10453

Email: elise.langan@bcc.cuny.edu
} 
Practices \& Council of Chief State School Officers, 2010). Monte-Sano et al. (2017) maintain that the CCSS standards require content-area teachers to adapt both their curriculum and pedagogy to support disciplinary literacy development. These shifts require changes in mindset while repositioning content in the classroom.

The discourse around integrated curricula has evolved into practices that distinguish between content instruction and the frameworks that help prepare students for twenty-first century careers. This distinction highlights the significance of employability, evaluated through college and career readiness skills, and includes the mastery of life-long skills such as collaboration, creativity, communication, and critical thinking (Battelle, 2019). Additionally, students must be able to recognize and investigate social problems in order to find workable solutions. The National Council of Social Studies Framework for Social Studies State Standards consists of: College, Career and Civic Life (National Council for the Social Studies, 2013). To ensure that students are critical thinkers who are actively engaged in social discourse, social studies classrooms provide opportunities for students to "develop the capacity to know, analyze, explain, and argue about interdisciplinary challenges in our social world" (National Council for the Social Studies, 2013, p. 6). More specifically, teachers who use an integrated curriculum allow students to closely examine a range of texts that can foster both critical thinking and disciplinary literacy. This integrated approach is antithetical to most students' and teachers' preference for the one-note rendition of textbooks (Langan, 2015; Jobrack, 2012; Wineburg, 2001). Nonetheless, textbooks remain teachers' preferred mode of instruction since they are reluctant to surrender their acquired lesson plans in favor of newer and more effective materials (Jobrack, 2012, p. 20).

If we are committed to helping our students become better readers, thinkers, and doers - who take action against injustices-we must provide opportunities for them to do so. One solution is to increase students' access to multi-perspective primary sources. By presenting various narratives, students can "make judgements about the credibility of conflicting sources of information, and can identify and make judgements about competing values that are at stake in a given situation" (Engle \& Ochoa, 1988, p. 51). The integration of social studies into literacy instruction has shed light on the importance of multiple sources that provide vital perspective for students to comprehend events and personalities (Saunders, Berson, \& Berson, 2014, p. 1). Another option is to foster student-centered inquiry by introducing processes such as the Inquiry Arc (Grant, 2013). The Arc is a tool that facilitates a process for examining "the nature of inquiry in general and the pursuit of knowledge through questions in particular" (National Council for the Social Studies, 2013, p. 12). By using this method, teachers help guide students through the process of inquiry to foster critical thinking, analysis, and exploration guided by self-generated questions-heuristics utilized by historians. Taking a disciplinary literacy approach, the Inquiry Arc facilitates inquiry in four ways: (1) Developing questions and planning inquires, (2) Applying disciplinary concepts and tools, (3) Evaluating sources and using evidence, and (4) Communicating conclusions and taking informed action (Grant, 2013, p. 322). This line of inquiry can lead to civic engagement when teachers foster opportunities for students to examine social issues in the social studies curriculum (Williams \& Maloyed, 2013; Monte-Sano, 2010, 2008). It can also help students reflect on their learning as they progress through the process by giving them a framework for approaching research, acquiring knowledge, and considering the significance of what they are learning. Within this context, disciplinary literacy instruction can help students to acquire the ability to read, think, and reason like historians as they work with historical texts, such as primary and secondary sources (Nokes, 2011, 2010; Wineburg, 2001).

In this paper, we explore the extent to which teachers who reframe their social studies lessons around primary sources for local contexts and issues can simultaneously foster students' inquiry and 
literacy. Herein, attention to local includes "culturally and linguistically relevant citizenship education" (Jaffee, 2016, p. 89) which considers the needs of diverse learners, values local knowledge, fosters community awareness, and civic involvement. "Global" is defined as knowledge of broader social issues including policies, events, and practices that are beyond the immediate community. We argue that social studies teachers can help students become critical thinkers by using primary sources as springboards for civic engagement, increased literacy, and inquiry.

\section{Review of the Literature}

Before the Common Core State Standards, more than seventy-five percent of reading in early grades was fiction (Duke \& Bennett-Armistead, 2003). Consequently, middle and high school students may have had less well-developed schema to unpack different topics due to limited exposure to social studies content during their formative years (Saunders, Berson, \& Berson, 2014, p. 1). Subsequent to the Common Core State Standards, studies have explored different ways to teach social studies including how to position it in the curriculum. Some research has explored use of inquiry-oriented pedagogy to study local history (Bermudez, 2015; Crocco \& Marino, 2017). Others have looked at the symbiotic relationship between literacy and content, particularly how to structure inquiry when working with diverse learners (Schenning et al., 2013). Disciplinary literacy departs from the traditional discourse on content-area reading by suggesting that "different literacy skills are needed for specific disciplines" (Bernstorf, 2014, p. 33). Despite the evidence documenting the benefits of integrated curricula, in many settings, social studies has become marginalized due to the competing priorities of testing (Heafner, 2017, 2018). For example, instead of a disciplinary literacy approach where students engage in authentic research by analyzing and questioning primary sources in social studies, emphasis is placed on content-area reading practices such as making connections, understanding text structure, and the use of techniques such as lists, group labels, and graphic organizers (Massey \& Heafner, 2004). Although these content-area practices are valuable to content literacy development, broader goals for writing proficiency rely on the student's ability to ask questions (writing arguments, analyzing and interpreting sources, and writing commentaries that help to contextualize historical and contemporary events, conducting a critique or evaluation, etc.). Integrated literacy practices that foster students' critical thinking and communication skills are vital components of student success in the twenty-first century (Battelle, 2019); however, teachers rarely learn how to teach writing in their preservice or in-service practicums (National Commission on Writing, 2003). As a result, only twenty-five percent of adolescents demonstrate proficiency on national writing assessments (National Center for Education Statistics, 2012). Lucey et al.'s (2014) survey of elementary and middle school social studies teachers found that whole class instruction was the approach used daily or frequently by all middle school teachers; most responded by using cooperative learning and higher order thinking daily or frequently; nonetheless, writing in middle school social studies was rare.

Bermudez (2015) argues that history, social studies, and civics fall short when promoting critical thinking. According to Bermudez (2015) critical thinking is often evident in "active inquiry-based learning...[t]o empower students to take charge of problems they face in real life, from abstract puzzles in intellectual endeavors to practical challenges of participating in a community" (p. 103). Bermudez (2015) suggests using a problem-posing framework when teaching social studies because it "is a tool that we use to raise critical questions that invite further investigation of claims, beliefs, and social 
practices that are commonly taken for granted" (p. 106). From a problem-posing perspective, critical inquiry is purposeful and contextualized, thereby localizing knowledge based on praxis and relevancy. This perspective allows students to challenge conventional knowledge and generate their own questions for further exploration. For example, Tucker (2018) illustrates how students' lived experiences and active participation in social issues, e.g., protests against police brutality, can foster class discussions and inquiry about social justice. Using a problem-posing approach can help to reframe dominant discourses and narratives that prompt students to link local occurrences to historical events. In addition, local analysis of issues allows for rich discussions about geography, providing the contextual factors that share commonalities with local narratives included or left out when constructing those stories (Tucker, 2018). Local knowledge helps inform the curriculum by including voices, perspectives, and experiences that were previously neglected or unknown. In classrooms that utilize these practices, students engage in inquiry grounded in local, authentic issues.

\section{Background and Context}

We designed and implemented a grant-funded professional development project called, "New York City as a Living Museum," which was created to expand the awareness and use of local primary sources and enhance in-service teachers' ability to bridge content, use close reading strategies, and employ effective pedagogy. We recruited participants by circulating an online application for in-service 3-12 teachers. Ten slots were available to early-career teachers, i.e., those who had taught for one to five years. Acceptance included a stipend and professional learning credits. The application was sent to The Gotham Center for New York History email lists, The New York City Department of Education email lists, Lehman College's School of Education graduate email lists, and Medgar Evers College's School of Education graduate email lists. We received 75 applications. In addition to providing information about their educational backgrounds and citations or honors, applicants were asked to answer a prompt: "Describe your views of teaching and learning, especially how you approach designing lesson plans." They were given a 500-word limit. Participants were selected based upon a peer-review process of evaluating their essays, their status as early career teachers, and geographic diversity, i.e., that all New York City boroughs were represented. There were no applicants from Staten Island.

Ten teachers were selected to participate; one had to drop out, leaving nine middle and high school teachers who brought a range of teaching experience to the project. In addition to teaching social studies, some taught special needs students. They worked in diverse school settings; over seventy-five percent of their students received free or reduced lunch in Title 1 schools. The majority of their students are African-American and second-generation immigrants. A pre-workshop survey showed that the teachers had prior knowledge of using primary sources and the Library of Congress website but many of them had not centralized the use of primary sources in their curriculum.

We collaborated with three local cultural institutions in New York City: The Museum of the City of New York, the New York Historical Society, and the Gotham Center for New York History. Although all of the institutions were located in Manhattan, we brainstormed a list of possible resources for teachers to utilize in the areas where they teach; for example, the Dyckman Farmhouse Museum in the Bronx, the Henry Street Settlement in Manhattan, and the Queens Museum. The institutions shared artifacts, curriculum materials, and guided participants in local tours. Presenters from the three partnering institutions demonstrated how the curricular materials available through their respective organizations could be implemented and/or used to supplement content across grades. 
Throughout each session of the summer 3-day workshop, presenters modeled how to merge content with pedagogical strategies. The workshop included presentations on various topics. The presenters used different methods to illustrate how to bridge content and literacy, how to use inquiry processes such as generating questions and using primary sources to answer questions, close reading strategies, and learning social studies content from primary source artifacts (Table 1).

Table 1

Examples of Workshop Activities

\begin{tabular}{|c|c|c|c|}
\hline $\begin{array}{c}\text { Workshop } \\
\text { Topic }\end{array}$ & $\begin{array}{c}\text { Content } \\
\text { Connection }\end{array}$ & Literacy Skills & Pedagogical Approach Modeled \\
\hline $\begin{array}{l}\text { Harlem } \\
\text { Renaissance }\end{array}$ & $\begin{array}{l}\text { Using primary } \\
\text { sources: Local } \\
\text { History, U.S. } \\
\text { History }\end{array}$ & $\begin{array}{l}\text { Making } \\
\text { connections: } \\
\text { Synthesizing } \\
\text { sources, asking } \\
\text { questions, } \\
\text { noticing/noting } \\
\text { details, making } \\
\text { inferences }\end{array}$ & $\begin{array}{l}\text { Collaborative/cooperative learning, } \\
\text { gallery walk: Images are posted around the } \\
\text { room. Students are given a limited amount } \\
\text { of time at each source. As they walk } \\
\text { around the room students walk around } \\
\text { jotting down what they see, questions they } \\
\text { have, connections between the sources. }\end{array}$ \\
\hline $\begin{array}{l}\text { Various } \\
\text { topics } \\
\text { selected by } \\
\text { students }\end{array}$ & $\begin{array}{l}\text { Locating primary } \\
\text { sources: Local } \\
\text { History, U.S. } \\
\text { History, } \\
\text { Global Studies }\end{array}$ & $\begin{array}{l}\text { Online/ } \\
\text { database } \\
\text { research, } \\
\text { inquiry, asking } \\
\text { questions }\end{array}$ & $\begin{array}{l}\text { Collaborative/cooperative learning, } \\
\text { student centered research: Students } \\
\text { identify a topic of interest, generate a list } \\
\text { of potential sources that can help answer } \\
\text { the question, and then conduct research } \\
\text { using the Inquiry Arc process. Throughout } \\
\text { the research process, the student reflects } \\
\text { on limitations and challenges encountered, } \\
\text { and how the research focus/question } \\
\text { evolves. }\end{array}$ \\
\hline $\begin{array}{l}5 \text { Boroughs } \\
\text { of New York } \\
\text { City }\end{array}$ & $\begin{array}{l}\text { Using artifacts: } \\
\text { Local History, } \\
\text { U.S. History }\end{array}$ & $\begin{array}{l}\text { Asking } \\
\text { questions, } \\
\text { making } \\
\text { connections, } \\
\text { creating/writing } \\
\text { stories, making } \\
\text { inferences }\end{array}$ & $\begin{array}{l}\text { Differentiating for multiple intelligences: } \\
\text { Artifacts and objects such as buildings in } \\
\text { the neighborhood and items from a } \\
\text { museum collection are used to help } \\
\text { students visualize and understand the } \\
\text { stories in history and the contexts in which } \\
\text { those stories emerged. Walking tours and } \\
\text { discussions about local history are used to } \\
\text { highlight the impact of global events on } \\
\text { the individual. }\end{array}$ \\
\hline
\end{tabular}

Throughout the professional development experience, presenters reminded participants that when planning their lessons, text selection is critical. In order to be developmentally appropriate, teachers were exhorted to choose texts that minimize the cognitive load for students (e.g., excerpts/chunks, 
visual texts including artwork, artifacts) so all students can be actively engaged. Throughout, participants were prompted to use intentional teaching (Epstein, 2007) while employing critical literacy as a framework to facilitate opportunities for students to interrogate texts (Behrman, 2006; Freire, 1983). They were continuously reminded that classroom discussions help improve students' writing outcomes. During the workshop, the presenters simulated the activities as students so the teachers could experience the task as a learner. Asking questions, drawing conclusions, and making connections were some overarching literacy skills across the presentations-all of which align with the Inquiry Arc. After each experience, the group reflected about what worked, what did not, and how it could be adapted for use in their own classroom.

\section{Methods}

We conducted a qualitative study to learn how the nine social studies teachers integrated primary sources into their unit plans, what kinds of texts they used, how (or if) they used disciplinary literacy practices, and why they made their instructional decisions. With emphasis on case study methods, we sought to take a close look at the teachers' practice to understand their instructional decision-making and how the 3-day workshop impacted their practice. Our research questions were:

1. How did the teachers integrate disciplinary literacy into their social studies instruction?

2. What types of pedagogy did they utilize?

3. In what ways did they integrate primary sources, literacy, and social studies?

To examine the research questions, a range of data sources were used including unit plans, instructional artifacts, interviews, post-workshop evaluations, and field notes. The unit plans were assigned as a culmination of the three-day professional development program. The teachers were asked to design a unit of 4-5 lessons that included primary sources from the Library of Congress and the cultural institutions we visited during the workshop. With the understanding that each teacher worked in a different context, there were no parameters placed on the specific lesson plan format, length, etc. However, we asked that the teachers: (1) reposition the primary sources at the center of their planning and (2) consider how to make local and global connections with their topics. They were also reminded to consult age-appropriate ELA standards. We collected the teachers' instructional artifacts which included PowerPoint, lecture notes, handouts, and the primary sources used to teach the lessons. After the units were implemented, we interviewed teachers about their decision-making when teaching their lessons. The interviews provided information on why the teachers made their instructional choices and their effects on students. On average, the interviews lasted 30 minutes by phone or Skype. The interview questions sought to determine the ways in which the workshop impacted teachers' instructional practice, what they learned about the outcomes and benefits when using primary sources, and how the primary sources were used during their units. Additional data were obtained from our field notes taken during the three-day workshop. During and after each workshop session, the co-directors of the project (co-authors) captured their observations and reflections about the teachers' practices, the workshop experience, and noted comments and reactions using a shared Google Doc. The teachers completed workshop evaluations at the end of each session. Evaluation questions captured information about the teachers' knowledge and use of primary sources. During the first session of the workshop, teachers also completed a presurvey to share their background knowledge and experience using 
primary sources.

Content and document analysis were used to analyze each data source independently. We looked carefully at the content and sought areas of convergence and departure from the workshop program goals. We also identified emerging themes or patterns between and among the sources. Our follow-up discussions helped to clarify and corroborate findings in addition to helping us see the impact of the workshops on the teachers' practice. For example, we each reviewed the teachers' unit plans to evaluate the content, use of primary sources, and the extent to which the strategies introduced in the workshops transferred into the teachers' units. Our discussions helped to clarify how the teachers' outcomes (the units they created and implemented) met the goals of the project; helped teachers incorporate more primary sources into their curriculum; helped teachers design learning opportunities for students to make local and global connections; and to what extent disciplinary literacy practices were utilized. We sorted the lessons to identify those that provided opportunities for students to make linkages between local and global concepts. Content analysis included an iterative process of recursively returning to the data to identify emerging themes. A spreadsheet was used to capture the teacher's name, unit topic, [social studies] themes/ content, types of primary sources, activities, potential student learning outcomes, applied workshop materials/ themes/ content, and the potential student learning outcomes, which were linked to the New York Common Core State Standards for English Language Arts and Social Studies/History. Similar to Lenski and Thieman (2013), we wanted to see what the teachers' lesson plans revealed about their integration of content and pedagogy to foster disciplinary literacy. This process helped us group the unit plans based on the following scale:

1. There was little evidence of transfer between workshop and lesson plans - few (can include 1-2) examples of strategies or pedagogies modeled during the workshop are evident in the units and teachers' reports during the interview.

2. There was moderate evidence of transfer - some, which can include 3 or 4 , examples of different strategies and/or pedagogies modeled during the workshop are evident in the units and teachers' reports during the interview.

3. There was significant evidence of transfer - multiple/ several (more than 5) examples of strategies and pedagogies modeled during the workshop are evident in the units and teachers' reports during the interview.

This process was used for each data source. When patterns were identified, they were grouped according to similar attributes. Continuously returning to the data helped to identify patterns across the sources to triangulate the evidence gleaned from the individual sources: lesson plans, field notes, instructional artifacts, interviews, and literature. We extracted examples of the patterns we found from each source to help corroborate the findings. Our analysis sought to determine the extent to which teachers fostered opportunities for students to develop content and disciplinary literacy in their social studies classrooms. We juxtaposed the lesson plans and teachers' reported practices in the interviews with recent research on content area reading.

\section{Results/Findings}

The first theme that we noticed across all nine teachers was the seamless integration of content area reading in their lesson plans. All of the teachers identified instructional objectives and activities throughout the social studies units to reinforce literacy skills. For example, we found that all of the teachers taught reading comprehension skills and incorporated writing; however, writing was mainly 
used as an assessment. Some teachers integrated note-taking strategies, such as double entry journal and Cornell note-taking, but there was no explanation that these protocols were introduced to students as tools of the discipline. The lessons focused on strategies for reading and writing in social studies/ history topics. For example, all of the teachers used a variety of graphic organizers as scaffolding tools to help students read and understand primary source texts. These texts included videos, journals, letters, photographs, cartoons. All of the lesson plans noted NCSS or New York State Social Studies standards and CCSS for English Language Arts /Literacy to address reading, writing, listening, and speaking standards. Five of the nine teachers linked their literacy instruction directly to primary sources when teaching specific social studies topics during their units (Table 2).

Table 2

Reading and Disciplinary Literacy Skills Introduced During Social Studies Lessons

\begin{tabular}{ll}
\hline \multicolumn{1}{c}{ Content Area Reading/Literacy } & \multicolumn{1}{c}{ Disciplinary Literacy } \\
\hline $\begin{array}{l}\text { Anna (high school teacher) } \\
\text { - Literacy skills - sources used to compare/ } \\
\text { contrast cultures }\end{array}$ & - Diana (middle school teacher) \\
& - Different types of primary sources used/ \\
& juxtaposed \\
& - Collaborative learning/ discussion \\
Gwen (middle grades teacher) & Erica (high school teacher) \\
- Analyzing primary sources, reading & - Learning about local history \\
documents and maps & - Connecting personal to the global \\
Discussion & - Student-led inquiry \\
Christina (high school teacher) & Collaborative learning/ discussion \\
- Essay writing & \\
Bnalyzing primary sources (Document & \\
Based Question) & \\
\hline
\end{tabular}

Note: All names are pseudonyms.

Although all of the teachers integrated literacy instruction in their content classrooms to support students' reading comprehension skills, they did so in different ways. As noted above, some teachers focused on note-taking, other emphasized writing, and some focused on close reading and analysis of texts, including primary sources. One teacher, Anna, a $9^{\text {th }}$ grade Global History teacher, stated in her interview that she likes using primary sources because they can "tell us what happened." She selects texts mainly to guide students to use close reading strategies and uses the primary source to reinforce literacy and comprehension skills. For example, in one lesson she used Cuneiform tables and other Babylonian sources, and a "Historical Thinking Chart" with categories (Sourcing, Contextualization, and Close Reading) as sentence starters for students to examine and discuss the texts. She shared that the use of close reading and graphic organizers moves students away from worksheets. Anna devised excellent assessments to track reading comprehension. 


\section{Guided Inquiry Helped Foster Discipline-Specific Literacy Skills}

The second theme emerging from the teachers' reports is that they simultaneously scaffolded students' literacy and inquiry skills through structured experiences with primary sources. Five of the nine teachers incorporated literacy instruction and aligned it with their social studies content lessons, but three teachers moved beyond content area reading to foster discipline-specific literacy skills. Gwen's practice is representative of the ways in which the three teachers used primary sources to foster historical thinking and analysis skills in their social studies class. When designing her unit, Gwen incorporated activities that focused on reading/literacy and social studies/ disciplinary skills. For example, she worked with her students to put primary sources in chronological order. She planned opportunities that provided students with a way to interact with primary sources using an analysis tool, "So it's like a game." She used guiding questions to scaffold students through the inquiry process, prompting them to think deeply about individual sources, making connections between sources, and making broader connections to the world around them. In contrast to the others, these teachers designed learning opportunities for student-centered inquiry.

During her interview, Gwen, a middle-grades teacher, explained that she participated in the threeday workshop because she sought more strategies on designing lessons, engaging with students effectively, and developing creative teaching ideas. We found that Gwen guided and scaffolded students' interaction with primary sources during her lesson on Child Labor. She said the goal of her lesson was for students to consider why labor laws became necessary. While teaching the content, she used literacy-focused questions such as "What is the main idea of this cartoon?" to prompt students' reading of primary sources. As students examined an image about Child Labor (Figure 1), she captured students' responses to her question about the main idea.

a. People eat anything in times of hunger.

b. Abuse of child labor by factory owners was a serious concern.

c. Too many children being born causes a food shortage.

d. Absolute monarchs are cruel to youngsters.

\section{Figure 1}

Image from Lesson on Child Labor

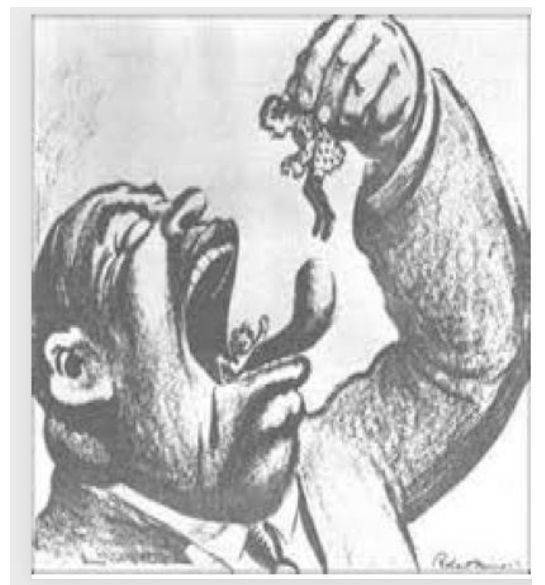

http://www.oldmagazinearticles.com/article-summary/1930s-child-labor\#.XIVelxLQiHs 
She used various graphic organizers, data charts, tables with statistics of child labor, and maps with the percentage of children working in different industries. Gwen stated during her interview that her students "like reading in chunks/excerpts"; she therefore uses activities such as a Gallery Walk-an instructional strategy introduced during the 3-day workshop-for her students to walk around the room and make written observations. Gwen reported that she used a Gallery Walk for three of her units: Industrial Revolution, Child Labor, and World War I. To guide her students' close reading of text, she used the Gallery Walk to juxtapose photos and political cartoons and prompts to get students to think deeply by using graphic organizers (see Figure 2).

\section{Figure 2}

\section{Graphic Organizer Used for Gallery Walk}

\section{Industrial Child Labor Walk}

Directions: Walk around the room and look at the pictures and read the texts that are posted. Take notes on what you see and read. Write about at least ten images/texts that you find compelling.

\begin{tabular}{|c|l|c|c|}
\hline$\#$ & $\begin{array}{c}\text { Observation/Information } \\
\text { (These sentence starters may help you take } \\
\text { notes. } \\
\text { I see... I notice...) }\end{array}$ & $\begin{array}{c}\text { Reaction/Analysis/Interpretation } \\
\text { (These sentence starters may help you write. } \\
\text { I was surprised...I think...I was confused...I } \\
\text { never knew...I's interesting that...) }\end{array}$ & $\begin{array}{c}\text { Questions/Issues/New Ideas and Thoughts } \\
\text { (These sentence starters may help you write. } \\
\text { I wonder...Maybe ...Perhaps...I'm curious...) }\end{array}$ \\
\hline Example & $\begin{array}{l}\text { I see three boys about 9 years old working on } \\
\text { a machine. All three boys look } \\
\text { undernourished. }\end{array}$ & $\begin{array}{l}\text { I am bothered that such young kids are doing } \\
\text { such dangerous work. }\end{array}$ & $\begin{array}{l}\text { Did their families send them to work because } \\
\text { they are desperately poor or did they just } \\
\text { want extra money? }\end{array}$ \\
\hline & & \\
\hline
\end{tabular}

Gwen's Gallery Walk during the Child Labor unit mainly consisted of eight pictures from Lewis Hine's compelling and encyclopedic pictures of Child Labor which are found on the Library of Congress Teacher's Page; the graphic organizer in her lesson was adapted from the LOC primary sources analysis tool introduced during the 3-day workshop. The graphic organizer was used primarily for note-taking. It served as a mechanism for students to collect information as they walked around and examined pictures of young children working in the mills and farms throughout the eastern and southern United States during the early to mid-1900s (see Figure 3).

\section{Figure 3}

Youngsters at Bibb Mill, Hine, L. (1909)

Youngsters at Bibb Mill No. 1, 1909

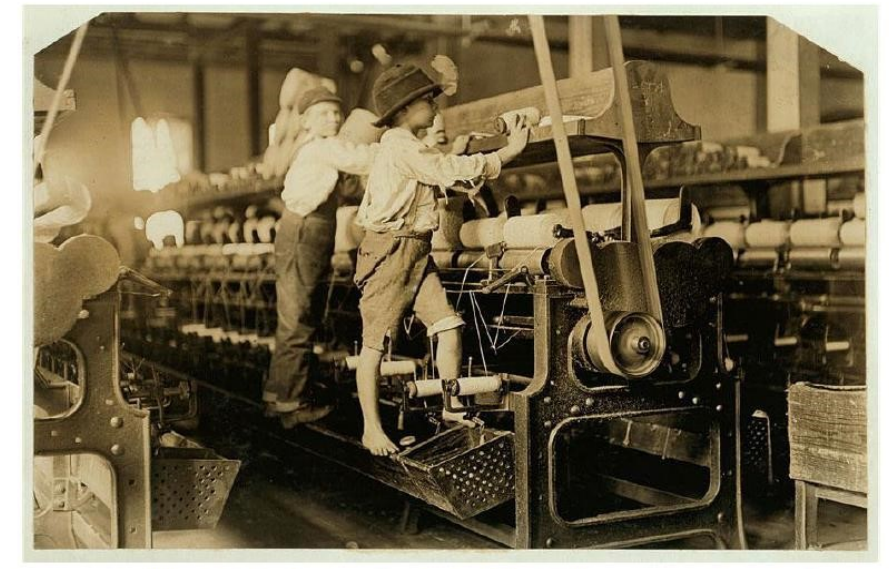

Some boys were so small they had to climb up on the spinning frame to mend the broken threads and put back the empty bobbins. Location:

https://www.loc.gov/item/2018674998/ 
Gwen reported that as her students circulate around the room for the Gallery Walk, they review the images, take notes about their observations, reflect on their reactions, and write questions they have about the images. These notes are then used in follow-up discussions with the class. In order to foster students' inquiry, they read about child labor throughout the unit to build their background knowledge. Students are then asked to review and compare historical and contemporary images and discuss any connections they can make to the images. During her units, Gwen consistently used contemporary sources. For example, during her unit on Child Labor, Gwen used Nike's "Just Do It" (Figure 4) to ask the question "Does child labor still exist?"

\section{Figure 4}

\section{Contemporary images used in Gwen's Child Labor Unit}

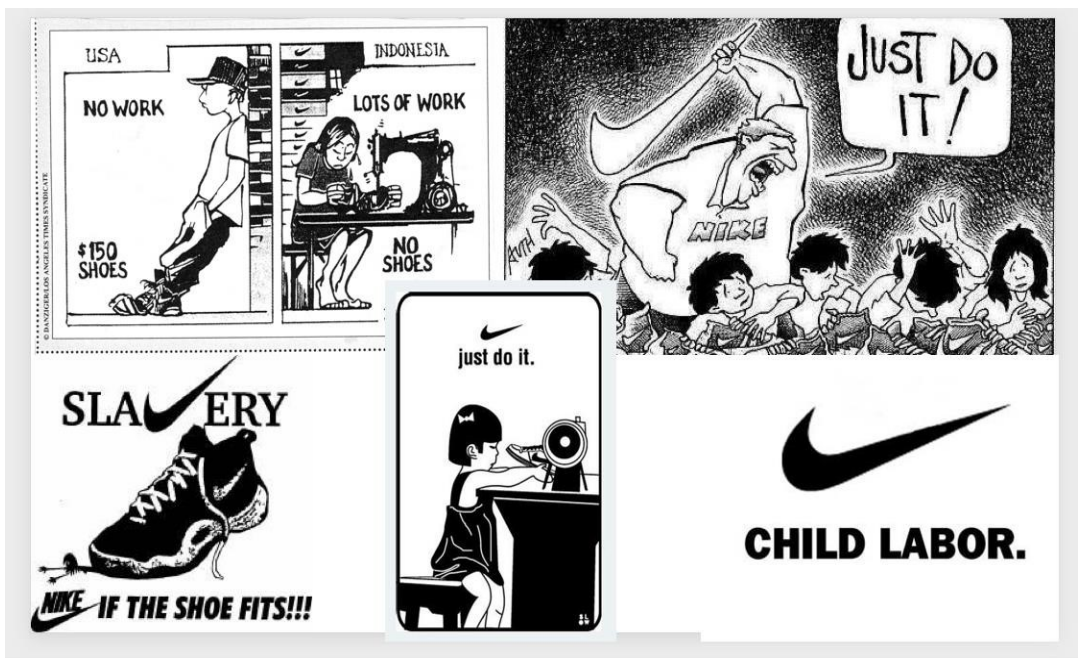

Gwen reported that after some class discussion, she asks students to reflect further by responding to the writing prompt: "Would you buy clothing made in Indonesia knowing that you are supporting child labor? Why or why not?" Gwen's prompts allow her students to examine their personal relationship to child labor. As Grant (2013) makes clear, there is an enormous difference between using questions to check for student understanding and "using questions to frame a teaching and learning inquiry" ( $p$. 325).

Similarly, Diana and Erica made connections to the students' lives during the unit plan to help connect students to the topic. Diana, a middle school teacher, fostered historical thinking and disciplinary literacy by introducing students to various tools and processes for analyzing sources. She modeled ways to analyze written documents and images. Erica, a high school teacher, cultivated student-led inquiry by scaffolding opportunities for her students to generate questions about sources introduced during the unit. She skillfully used the primary sources to generate discussions about larger topics. Similar to Tucker (2018), Erica created space for students to explore their personal histories and narratives within the local community to unearth local stories that led them to civic action. Throughout the summer professional development sessions, the teachers mentioned that in order to get students' attention, you have to help them see how topics connect directly to their lives. Erica proved particularly adept at making relevant linkages to pique her students' interest.

Sharon, a middle-grades teacher, was less successful in applying disciplinary literacy strategies in 
her Industrial Revolution lesson plans-mainly because she asked students to provide oral responses to prompts rather than having them produce much writing. When they were asked to write, it was according to the Frayer Model-a graphic organizer that relies on word analysis and vocabulary building versus the formation of declarative sentences to create well-crafted essays.

\section{Conclusion}

Crocco and Marino (2017) believe that placing inquiry at the center of practice helps teachers develop a better understanding of how to foster literacy. Lesson planning should be a crucial part of integrating comprehension strategies with content (Tejero Hughes \& Parker-Katz, 2013). According to Shifflet and Hunt (2019), teachers need to "develop an understanding of the purposes of integration and an appreciation for how the concepts and disciplinary literacy skills learned in social studies prepare students to be active citizens in the world" (p. 248). While the nine teachers sought ways to engage students in content area reading, some fell short in integrating literacy. All of the teachers incorporated primary sources into their unit plans for teacher modeling, small group work, and independent practice. Most of the lessons indicated that students worked with primary sources in groups or independently. Some teachers used sources for skill-building-specifically content area and/or disciplinary literacy skills. Three teachers in our study, Gwen, Diana and Erica, used a disciplinary literacy approach where they connected students' local, lived experiences to broader, more contemporary events, e.g., social justice issues, which indicates significant evidence of transfer. All three were adept at promoting discipline-specific literacy skills. Moreover, they embedded multiple forms of writing exercises throughout their lessons.

Social studies teachers should not utilize an either/or approach toward content-area reading and disciplinary literacy. Students need both. With regard to disciplinary literacy, students require an understanding of the discipline in order to read, write, and speak. This includes using the vocabulary and approaches which are germane to the discipline. With regard to content-area reading, students need content-area knowledge and reading/literacy skills to read and understand different kinds of texts. The question remains as to how teachers can merge these two constructs into a more integrated approach. Teachers who take a multi-disciplinary approach are able to join these pieces together which exemplifies the need for increased teacher preparation and professional development to provide equal focus on content, disciplinary literacy, and pedagogical methods. Sung and Yang (2013) contend that teachers' knowledge, specifically their disciplinary knowledge, influences their pedagogy. We found that in most of our teachers' classrooms, primary sources were mainly used for skill-building-not for knowledge generation or developing theories of historical ideas. Few teachers in our study provided an environment for students to make local and broader, global connections to engage in disciplinary literacy. Although Gwen, who teaches $9^{\text {th }}$ grade Global History, did connect her students' experiences to the curriculum using Lewis Hine's photos, she could have asked them to find maps to plot the geography of child labor around the globe and to draw conclusions about the local economic, political, and social dynamics of child labor. Utilizing Hine's photos in this way could have helped her students to further contextualize the policies that eventually arose against child labor. Her students could have investigated who the suppliers are for their local clothing stores and taken action to increase community awareness. This missed opportunity reiterates that literacy instruction in social studies prioritizes skillbuilding and content area reading in most social studies classrooms rather than historical inquiry (Korbin, 1996). However, Gwen successfully incorporated reading and writing strategies in her 
lessons and used a "Historical Thinking Chart" which includes: Sourcing, Corroboration, Contextualization \& Close Reading-all of which act as sentence starters. She also utilizes graphic organizers to get her students away from worksheets.

As facilitators, we addressed literacy (Smith, 2004) during the three-day professional development seminar, e.g., the use of the Library of Congress Primary Source Analysis Tool (see:

http://www.loc.gov/teachers/primary-source-analysis-tool//) close reading strategies, making connections to ELA standards; however, we should have been more prescriptive in our approach both during and after the sessions. For example, when subsequently articulating the criteria for teachers' units, we required that primary sources be at the center of their planning and that they make local and global connections with their topics. We should have been more specific and required that they implement literacy strategies throughout their units instead of "recommending" that they consult ageappropriate ELA standards. We wondered why Gwen was so expert at incorporating disciplinary literacy throughout her social studies lessons; we subsequently learned that she routinely uses the Stanford History Education Group's resources (see: https://sheg.stanford.edu/) which entail: sourcing, contextualizing, corroborating, and close reading. Ideally, the goal of disciplinary literacy and social studies integration could have been more fully realized by an additional half-day session to focus on its inclusion and implementation. When comparing our middle and secondary teachers' use of disciplinary literacy processes, our study reifies Saunders, Berson and Berson's (2014) finding that non-fiction texts, such as primary sources, must be given far greater emphasis in elementary and middle school to better prepare students for secondary and higher education. Students need to engage in many more "literacy acts" (Smith, 2004), e.g., produce more written texts, in addition to analyzing more complex texts in elementary, middle, and secondary school settings. The failure to do so will result in our students struggling in reading, writing, critical thinking, and civic participation. Professional development that places equal emphasis on the integration of primary sources, disciplinary literacy, and pedagogical methods is worth replicating.

\section{Declaration of Conflicting Interests}

The author declared no potential conflicts of interest with respect to the research, authorship, and/or publication of this article.

\section{Funding}

This research was funded by The Teaching with Primary Sources (TPS) Eastern Region program at Waynesburg University. The mission of the Library of Congress Teaching with Primary Sources program is to build awareness of the Library's educational initiatives; provide content that promotes the effective educational use of the Library's resources; and offer access to and promote sustained use of the Library's educational resources. The program was in coordination with the Gotham Center for New York History's (CUNY) K-12 Education Program. We would like to thank Ms. Julie Maurer, the Gotham Center's Education Director, for her considerable efforts on behalf of the project.

\section{ORCID iD}

Elise Langan (iD https://orcid.org/0000-0003-2036-7064

Salika A Lawrence (iD https://orcid.org/0000-0001-9877-9443 


\section{References}

Battelle for Kids (2019). Framework for 21st century learning. http://www.battelleforkids.org/networks/p21/frameworks-resources

Behrman, E. (2006). Teaching about language, power, and text: A review of classroom practices that support critical literacy. Journal of Adolescent \& Adult Literacy, 49(6), 490-498. https://doi.org/10.1598/jaal.49.6.4

Bermudez, A. (2015). Four tools for critical inquiry in history, social studies, and civic education. Revista de Estudios Sociales, 52, 102-118. https://doi.org/10.7440/res52.2015.07

Bernstorf, E. (2014). Disciplinary literacy: A new concept or old as the hills? Kodály Envoy, 40(4), 3335.

Crocco, M., \& Marino, M. (2017). Promoting inquiry-oriented teacher preparation in social studies through the use of local history. Journal of Social Studies Research, 41(1), 1-10. https://doi.org/10.1016/i.jssr.2015.11.001

Engle, S., \& Ochoa, A. (1988). Educating for democratic citizenship. Teachers College Press.

Epstein, A. (2007). The intentional teacher: Choosing the best strategies for young children's learning. National Association for the Education of Young Children.

Freire, P. (1983). The importance of the act of reading. Journal of Education, 165(1), 5-11. https://www.jstor.org/stable/42772842

Grant, S. (2013). From inquiry arc to instructional practice: The potential of the C3 Framework. Social Education, 77(6), 322-326.

Heafner, T. (2018). Elementary ELA/Social Studies integration: Challenges and limitations. Social Studies, 109(1), 1-12. https://doi.org/10.1080/00377996.2017.1399248

Heafner, T. (2018). More social studies?: Examining instructional policies of time and testing in elementary school. Journal of Social Studies Research, 42(3), 229-237. https://doi.org/10.1016/i.jssr.2017.08.004

Hughes, M., \& Parker-Katz, M. (2013). Integrating comprehension strategies into social studies instruction. Social Studies, 104(3), 93-104. https://doi.org/10.1080/00377996.2012.691570

Jaffee, A. (2016). Community, voice, and inquiry: Teaching global history for English Language Learners. Social Studies, 107(3), 89-101. https://doi.org/10.1080/00377996.2016.1140626

Jobrack, B. (2012). Tyranny of the textbook: An insider exposes how educational materials undermine reforms. Rowman \& Littlefield.

Langan, E. (2015). Using multiple-perspective primary sources to enhance preservice teachers' understandings. Teacher Education \& Practice, 28(4), 617-626.

Lenski, S., \& Thieman, G. (2013). What work samples reveal about secondary pre-service social studies teachers' use of literacy strategies. Teacher Education Quarterly, 4O(1), 6379.

Lucey, T., Shifflet, R., \& Weilbacher, G. (2014). Patterns of early childhood, elementary, and middlelevel social studies teaching: An interpretation of Illinois social studies teachers' practices and beliefs. SocialStudies, 105(6), 283-290. https://doi.org/10.1080/00377996.2014.945641

Massey, D., \& Heafner, T. (2004). Promoting reading comprehension in social studies. Journal of Adolescent \& Adult Literacy, 48(1), 26-40. https://doi.org/10.1598/jaal.48.1.3

Monte-Sano, C., De La Paz, S., Felton, M., Piantedosi, K., Yee, L., \& Carey, R. (2017). Learning to teach disciplinary literacy across diverse eighth-grade history classrooms within a districtuniversity partnership. Teacher Education Quarterly, 44(4), 98-124. 
Monte-Sano, C. (2010). Disciplinary literacy in history: An exploration of the historical nature of adolescents' writing. Journal of the Learning Sciences, 19 (4), 539-568. https://doi.org/10.1080/10508406.2010.481014

Monte-Sano, C. (2008). Qualities of historical writing instruction: A comparative case study of two teachers' practices. American Educational Research Journal, 45(4), 1045-1079. https://doi.org/10.3102/0002831208319733

National Center for Educational Statistics. (2012). The nation's report card: Writing 2011. http://nces.ed.gov/nationsreportcard/pubs/main2002/2003529.asp

National Commission on Writing in America's Schools and Colleges. (2003). The neglected " $R$ ": The need for a writing revolution. http://www.collegeboard.com/prod downloads/writingcom/neglectedr.pdf

National Council for the Social Studies. (2013). The College, Career, and Civic Life (C3) Framework for Social Studies State Standards: Guidance for enhancing the rigor of $K-12$ civics, economics, geography, and history. National Council for the Social Studies. https://www.socialstudies.org/standards/c3

National Governors Association Center for Best Practices \& Council of Chief State School Officers. (2010). Common Core State Standards for English language arts and literacy in history/social studies, science, and technical subjects. http://www.corestandards.org/assets/CCSSI ELA\%20Standards.pdf

Nokes, J. (2011). Recognizing and addressing the barriers to adolescents' "reading like historians." History Teacher, 44(3), 379-404. https://www.jstor.org/stable/41303991

Nokes, J. (2010). Observing literacy practices in history classrooms. Theory and Research in Social Education, 38(4), 515-544. https://doi.org/10.1080/00933104.2010.10473438

Saunders, B. (2014). Dear Senator: Young citizens explore civics through literacy. The Councilor, 75(2), 1-11.

Schenning, H., Knight, V., \& Spooner, R. (2013). Effects of structured inquiry and graphic organizers on social studies comprehension by students with autism spectrum disorders. Research in Autism Spectrum Disorders, 74), 526-540. https://doi.org/10.1016/i.rasd.2012.12.007

Shifflet, R., \& Hunt, C.. (2019). "All teaching should be integration”: Social studies and literacy integration in preservice teacher education. Social Studies, 110(6), 237-250. https://doi.org/10.1080/00377996.2019.1635978

Smith, F. (2004). Understanding reading: A psycholinguistic analysis of reading and learning to read. Routledge.

Sung, P. \& Yang, M. (2013). Exploring disciplinary background effect on social studies teachers' knowledge and pedagogy. Journal of Educational Research, 106(1), 77-88. https://doi.org./10.1080/00220671.2012.658453

Sweeney, M., \& Townsend, D. (2018). An analysis of discipline-specific academic language learning in middle-school students. Middle Grades Research Journal, 12(1), 9-21.

Tucker, T. (2018). "Where I come from it's like this": African American lens and the critical role of the local south in teaching social justice. South: A Scholarly Journal, 50(2), 212-224.

Williams, J., \& Maloyed, C. (2013). Much ado about Texas: Civics in the social studies curriculum. History Teacher, 47(1), 25-40.

Wineburg, S. (2001). Historical thinking and other unnatural acts: Charting the future of teaching the past. Temple University Press. 